\title{
Suicide Experiments Due to Unmet Love Needs in Jhumpa Lahiri's Hell-Heaven Story
}

\author{
Tomi Arianto ${ }^{1}$ \\ Universitas Putera Batam (UPB), Batam, Indonesia \\ tomy2088.ta@gmail.com \\ Ambalegin $^{2}$ \\ Universitas Putersa Batam (UPB), Batam, Indonesia \\ abhi140475@gmail.com
}

\begin{abstract}
This study was conducted to test the hypothesis of the Maslow hierarchy of needs through personality of the Aparna as the main character in the story of Hell Heaven by Jhumpa Lahiri. Maslow formulates 5 levels of hierarchy of needs that each person has, namely; physiology, security, love and belonging, appreciation, and self-actualization. The need for love is at the third level of Hirarchi of need Maslow. This theory assumed that a whole person is constantly motivated by one or more needs where people have the potential to grow towards psychological health, namely self-actualization. By using a qualitative descriptive method and coherent analysis, this study attempted to answer two research variables, namely the disclosure of the inability of the Aparna character to the needs of love and the causes and consequences of this lack of fulfillment. The results of this study indicate that Maslow's Hierarchy of Needs theory can be applied to analyze Aparna character's personality. It can be seen when a person has a disability in a certain level, he will be motivated to meet those needs before meeting other levels of need. This deficiency can also trigger a disease called pathology even to methapathology.
\end{abstract}

Keywords : Hierarchy of need, Love and Belonging, Suicide, and Hell-Heaven Story

\section{INTRODUCTION}

\subsection{Background}

Love is one of the needs that

must be possessed by every human being. Love is not only limited by two human partners, but also includes the love that is felt from various things including the environment, family, friends or friends, and so forth. Since childhood, humans have had a hierarchical need for love and affection. Someone will do anything 
to meet the need for love, whereas someone who loses the need for love can experience certain psychological disorders or psychopathology.

Fromm in Hall (1993) said that the most powerful impulse from human beings is the drive to unite among individuals. Love is defined as the unity between people while maintaining their integrity and individuality. Love is an active force in a person, who on the one hand eliminates feelings of isolation, and is isolated. But on the other hand it also retains the personality of each person. The basic elements that always exist in all forms of love are; attention, responsibility, respect and understanding.

Reflections on the need for love were also found in the Aparna character in the Hell-heaven short story by Jhumpa Lahiri. Motivation to fulfill Aparna's love needs culminated after he met Pranab Chakraborty, a man from Calcuta who had immigrated to England. Even though he already has a husband, he still wanted to get the love needs of others because he felt he didn't get fulfillment of love from her husband through his family matchmaking. From this, the author tried to identify the problem in the short story, namely the absence of love for the figure of Aparna and wanted to further analyze the causes and consequences.

The theoretical approach used to assist this analysis is Maslow's
Holistic-Dynamic and the limitation of research focus on the character Aparna which is identified as having a lack of need for Love and belonging. In general Maslow in Feist (2010) formulated 5 levels / levels of hierarchy of needs that each person has, namely; physiology, security, love and existence, appreciation, and selfactualization. The need for love is at the third level, so the authors conclude that the Aparna figure has passed the basic stages of Physiology and security needs. There are two research formulation that tried to analyzed by researcher; 1) How does the impotence of Aparna's character fulfill the needs of love and existence depicted in the Hell-Heaven Short Story by Jhumpa Lahiri. 2) Why Aparna's need for love and existence not fulfilled.

\subsection{Synopsis}

Aparna is the second subject told by the narrator in the HellHeaven story. It is said that Aparna Marriage with her husband as the result of matchmaking, a tradition that is still often found in India. The marriage of Aparna and her husband certainly did not begin with a love bond between both of them. After marriage, she immigrated to England along with her husband's duties as a Microbiology researcher at one of the UK Universities.

Since immigrated, Aparna didnot interested in socializing with the environment and changing the 
distinctive appearance of the area she wear. His first introduction with Pranab Chakraborty, a fellow immigrant from Calcuta, turned out to grow the seeds of love for Aparna and the new color for her, moreover the attention and affection that Pranab gave her which she certainly did not get from her husband. Disappointment arose when Pranab knew Deborah, a woman from America who later became his wife. This of course had an impact on Aparna who had felt that her love needs were a little fulfilled, because Pranab's love had already switched to Deborah. The effect also triggers its own depression, changing attitudes and even suicidal ideation by Aparna. After Pranab's 20 years of marriage, Aparna tried to fulfill the need for love by returning to his family and continuing his study of the library at a university.

\section{LITERATURE REVIEW}

2.1. Theory of the Research Abraham Maslow's Personality Theory has several names called as humanistic theory, transpersonal theory, needs theory, but Maslow more often called it a holistic-dynamic theory because this theory assumes that the whole person is constantly motivated by one or more needs and that people have the potential to growing towards psychological health, namely self-actualization. To fulfill one's self-actualization one must meet lower levels, such as physiological needs, security, love and appreciation, to achieve selfactualization. The five levels of these needs are then formulated by Maslow to form a conative needs hierarchy, which means that these needs have a motivating or motivating character (Maslow in Feist, 2010).

The need for love is a need at the third level of the formulation of Maslow's hierarchy of needs. So, to achieve this, someone has fulfilled or at least fulfilled before, namely Physiology and Security Needs. Physiological Needs according to Maslow in Feist (2010) are the most basic needs of every human being, including food, drinking water, oxygen, body temperature, etc. While the need for security includes physical security, stability, protection, freedom from threatening forces such as war, terrorism, disease, fear of anxiety, riots, natural disasters, etc. While the need for security includes physical security, stability, protection, freedom from threatening forces such as war, terrorism, disease, fear of anxiety, riots, natural disasters, etc. Furthermore, at the third level is the need for love After people fulfill their physiological and security needs, they become motivated by the need for love and existence, such as the desire to be loved, friends, being part of a family, having a partner and children, community environment, relating to other humans, etc. Love and existence according to Maslow also includes several aspects of sexuality 
and relationships with other humans and also the need to give and get love. After that level is fulfilled, then one can be free to pursue the need for rewards such as honor, reputation and self-esteem, fame, etc. Furthermore, the next level of motivation is to fulfill the need for self-actualization.

According to Maslow failure to fulfill one of the basic needs can lead to several diseases. Likewise, the lack of fulfillment of the need for love caused by contradictions with the need for love as explained above will cause psychological illness or pathology. When a person experiences a lack of love needs, a person becomes defensive, too aggressive, or even awkward in a social environment. The highest level reaches metha pathology as the absence of values, loss of meaning in life, depression and even the desire to commit suicide. It does not rule out the possibility of various efforts made by someone to meet the need for lack of love, such as seeking the attention of others to get love, cheating when the need for love is not fulfilled from their partners, etc. All of these things are someone's motivation to hold back or fulfill the needs for their shortcomings.

\subsection{Previous Study}

The research about Hellheaven story by Lahiri using Maslow's theory is indeed still not done. But there are several studies that have contributed significantly in this study. State of art from this study lies more in the comparison of other studies that use the same formal object with different data sources or vice versa. The following researchers describe several studies that have contributed much to the achievements of this research.

A journal written by Sugate (2013) entitled home, hybridity and love: diasporic relocations In jhumpa lahiri's hell-heaven can be calculated as one of the important studies that contributed to the development of this idea. This study used a postcolonial approach with Bhabha's theory of hybridity associated with love and diasporic relocation. Sugate proved that Pranab was a representation of the diasporic person from Bengali who was living in United Stated. This story also showed the assimilation and ethnicity that is ambivalence and hybrid of character.

The second research written by Roy (2019) entitled Illicit Motherhood: Recrafting Postcolonial Feminist Resistance in Edna O'Brien's The Love Object and Jhumpa Lahiri's Hell-Heaven. This study also used the post colonialism approach by looking at women's resistance in story narratives. This study showed that postcolonial feminist fiction reversed this tradition through constructing the "home and female-body" as sites of possible resistance, both colonialism and patriarchy. 
Futhermore, a journal written by Arianto (2018) entitled Indoctrination Against Women in "The Lowland" by Jhumpa Lahiri.

This research used different novel but the same author, Jhumpa Lahiri. Arianto used the Feminist approach to analyze Lowland novels, specifically Walter theory about indoctrination toward woman. The results of this study indicate that Indoctrination contestation in the novel The Lowland is divided into four forms; piety, purity, submissiveness and domesticity. This can be seen from the norms that apply in the community, customs, culture, and actions taken by each character in each story.

All of the previous research above certainly contributed to the development of ideas in this study. But still, the limitations of research from formal objects or material objects of this study are different from previous studies. This study focused on the form of suicide attempts because of the inability to love with the disclosure of Maslow's hierarchical personality. So far, related research has not been found by researchers so researchers are interested in continuing to develop this research further.

\section{RESEARCH METHOD}

Faruk (2012) stated that to test the hypothesis which is the result of theoretical deduction, it is necessary to use inductively obtained empirical data which must then be analyzed so that inter data relationships are found that represent represent relationships between facts as stated in theories and hypotheses. The first thing to do is to determine material objects and formal objects. In this study, the material object is the Hell Heaven Story novel and its formal object is Suicide Experiments Due to Unmet Love Needs.

\subsection{Method of collecting data}

The method and technique of data collection are basically a set of methods or techniques that are extensions of the human senses because the aim is to collect empirical facts related to research problems. The data in this study are qualitative data because they are in the form of statements about the content, characteristics, circumstances and everything contained in the material object of this study, namely Hell Heaven Story By Jhumpa Lahiri. The data that will be collected from this story are related to various forms of suicide experiments caused by the lack of love.

\subsection{Method of analysis data} the method of data analysis is a set of methods or techniques of research that are extensions of the human mind because their function is not to collect data, but to look for inter data relationships that will never be self-declared by the data in question. Data analysis in this study 
was conducted by looking at the relationships between textual units found in Hell-heaven stories in relation to Abraham Maslow's hierarchical theoretical concept of need. In addition, it will also be seen the relationship of the textual units with data originating outside the Hell Heaven story. Among them are texts relating to the culture and customs of Indian society.

\section{RESULT AND DISCUSSION}

In Maslow's theory of hierarchy of needs, the need for love and existence occupies the third position after the fulfillment of physiological and security needs. Seeing the economic condition of her husband as a researcher in America, it can be considered that economically not experiencing shortages so that his physical needs such as eating, drinking, shelter, sex have been fulfilled because he already has a husband who has sufficient income to meet their physiological needs. Then it can be considered that physiological needs have been fulfilled.

After the physiological needs are fulfilled so that the mind is not focused on obtaining physiological needs, the next need arises in terms of the need for security. The need for security mentioned by Maslow in Golbe (1992) in the form of order and stability. Living in a country that has a clear legal system such as America has provided sufficient security for its citizens. Similarly, Aparna, although the narrative stated that there are areas that are not safe, but Aparna's residence is relatively stable and safe. Moreover, the need for security is not a need that is hard to achieve by Aparna figures, so that these needs are considered to have been fulfilled.

\subsection{Aparne's love and Belonging needs \\ Maslow stated that after one} level of need has been met, human needs will immediately move to the next level of need, "if the physiological needs and the need for security have been fulfilled, then the need for love, affection and belongingness arised. (Jerome, 2013)". If these needs cannot be met, humans will get psychological disorders.

After two basic needs are met Aparna needs love. But she can't get that love. Love by most people is often obscured by sexuality. However, according to Maslow, referring to Decarvalho (1991), love is not just a sexual need but rather, "the situation is understood in depth and accepted with all my heart."

\subsection{Less of Love and Belonging from Family \\ Aparna's marriage with her} husband is the result of matchmaking, a tradition that is still common in India. Marriage between Aparna and her husband did not begin with a love bond between the two individuals. It was stated that the reason the two 
individuals were married was because Aparna's husband was only allowed to leave India if he had a wife. "He is married, my mother to placate his parents; They were willing to accept his long desert as he had a wife (Jhumpa Lahiri, 2008)". Therefore, Aparna was only married as a condition by her husband to get permission from her family to work abroad.

After being married for several years, Aparna still did not get love from her husband. He does not get attention, understanding, affection and belonging.

"I began to pity my mother; the older I got, the more I saw what a desolate life she led. She had never worked, and during the day she watched soap operas to pass the time. Her only job, every day, was to clean and cook for my father and me ... When my mother complained to him about how much she hated life in the suburbs and how lonely she felt, he said nothing to placate her. 'If you are so unhappy, go back to Calcutta,' he would offer, making it clear that their separation would not affect him one way or the other (Jhumpa Lahiri, 2008)".
Based on the quotation above, it is known that Aparna's husband did not care about what she felt. When she felt lonely her husband doesn't try to reassure her. He moreover told Aparna to return to Calcutta. So the love in Roger's definition is a deeply understood situation not given by Aparna's husband to him. Aparna's relationship with her husband is a husband and wife relationship that is lawful but without love, only sex.

Likewise with her daughter. Usha, who has lived in America since childhood, is surrounded by American culture. However, Aparna forced her son to maintain Indian culture and culture in America. Feeling incompatible with what her mother taught, Usha rebelled. Their relationship that was initially close enough began to stretch as Usha grew up. Usha, who grew up, modeled more on her father than her mother. She imitated her father by ignoring and demeaning her mother. Based on the statements that have been stated above, it is known that Aparna does not get the love of her husband or her own daughter

\subsection{Less of Love and Belonging from Society \\ Human does not only need} love and affection from their families but also other people in their groups. Aparna is an Indian Immigrant who settles in America. She cannot adjust to the American environment. Do not like culture, customs do not even 
accept the presence of America in her family. She experienced feelings of isolation from her own environment. In fact, she is not familiar with his neighbors. She did not find a place in his group where he could get love.

\subsection{Pranab Chakravorty}

Fulfillment while the Need for Love and Affection

Getting unloved from her family, Aparna found a man namely Pranab Charavorty, a student who was studying in America. "Pranab Kaku listened to these stories with interest, absorbing the vanishing details of her past. He did not turn ear to her nostalgia, like my father, or listen to uncomprehending, like me". Pranab gives attention, affection, appreciation that is not obtained by Aparna in his family and environment. He considered Aparna as an older brother but Aparna considered Pranab more than a younger sibling.

The love given by Pranab Kaku is only temporary because he then has a girlfriend and is married. The loss of Pranab Chakravorty left a deep sense of loss in Aparna. He returned unable to fulfill his need for love. This loss and lack of love raises what Maslow called psychopathology or psychiatric disorders. Maslow states that thirst for love is a kind of deficiency. When these needs arise when they are not fulfilled, they cause shortages.

Feeling lonely, unappreciated, loved and loved causes disturbances to Aparna's psychological condition. Maslow does not explain in detail the symptoms of mental disorders such as what can happen to sufferers of lack of love and recognition. In the case of Aparna psychiatric disorders were known from his desire to commit suicide by burning himself.

\section{Conclusion}

Need and belonging as formulated in Maslow's Hierarchy of Needs is the third level after the need for Physiology and security is fulfilled. Aparna's figure in the story has at least been fulfilled in terms of physiological and security needs. But at the level of need for love, she experienced lack of fulfillment. This is influenced by many factors; Matchmaking, lack of love from her husband, and an environment that does not bring love. That's why she has the motivation to make love for love by approaching Pranab but also doesn't last long because she is married to someone else. It is this love affection which later gave birth to the pathology experienced by Aparna in the form of depression, alienating them from the environment, even to the desire to commit suicide.

The results of the analysis, it was found that Maslow's Hierarchy of Needs theory could be applied to analyze the personality of the character Aparna in this story. When a person has a disability in a certain level, she will be motivated to fulfill 
the need in order to get selfactualization. If the fulfillment failed, this deficiency can also trigger a disease called pathology even to metapatology.

\section{REFERENCES}

Arianto, T. (2018). Indoctrination Against Women in "The Lowland" by Jhumpa Lahiri. OKARA, 12(2), 153-166. https://doi.org/http://dx.doi.org /10.19105/ojbs.v12i2.1935

Decarvalho, R. J. (1991). The Growth Hypothesis in Psychology: The Humanistic Psychology of Abraham Maslow and Carl Rogers. New York: Edwin Mellen Pr.

Faruk. (2012). Metode Penelitian Sastra, Sebuah Penjelajahan Awal. Yogyakarta: Pustaka Pelajar.

Feist, \& F. (2010). Theory of personality. Buku 1 edisi 7. Jakarta: Salemba Humanika.

Fromm in Hall. (1993). The anatomy of human destructiveness. Harmondsworth, Middlese: Penguin Books.

Golbe, F. G. (1992). Mazhab ketiga psikologi humanistik Abraham Maslow. Yogyakaarta: Kanisius.

Jerome, N. (2013). Application of the
Maslow's hierarchy of need theory; impacts and implications on organizational culture, human resource and employee's performance. IJBMI, 2(3), 39-45. Retrieved from www.ijbmi.org

Jhumpa Lahiri. (2008). Unaccustomed Earth. London: Penguin Books.

Hall, Calvin dan dkk. 1993. Teori-Teori Psikodinamik (Klinis).Yogyakarta: Kanisius

Roy, D. (2019). Illicit Motherhood: Recrafting Postcolonial Feminist Resistance in Edna O'Brien's The Love Object and Jhumpa Lahiri's Hell-Heaven. Humanities, 8(29). https://doi.org/10.3390/h80100 29

Sugate, A. S. (2013). Home, hybridity and love: diasporic relocations In jhumpa lahiri's hell-heaven. journal of higher education and research society refered international, 1(1), 179-186. Retrieved from https://herso.org/issue-1-vol-1oct-2013/

Suryabarata, Sumadi.2007.Psikologi Kepribadian.Jakarta: Raja Grafindo dikutip tanggal 31 maret 2015 http://www.psychologymania.co $\mathrm{m} /$ 
Journal IdeBahasa Vol.1 No. 1. Juni 2019

$50 \mid \mathrm{P}$ ag e 